\title{
Effects of Aloe vera utilization on physochemical and microbiological properties of Turkish dry fermented sausage
}

\author{
Eyüp Uşan ${ }^{1}$ Gülden Başyiğit Kılıç ${ }^{1}$ (1) Birol Kılıç ${ }^{2}$
}

Revised: 9 May 2021 / Accepted: 16 June 2021 / Published online: 24 July 2021

(C) Association of Food Scientists \& Technologists (India) 2021

\begin{abstract}
The study aimed to determine the minimum inhibitory concentration of Aloe vera extracts obtained by different extraction methods on eight strains from five different pathogens (Pseudomonas fluorescens, Listeria monocytogenes, Salmonella spp., Escherichia coli and Staphylococcus aureus) in the first phase and utilize Aloe vera extract in sausage processing in the second phase. Sausages were evaluated for thiobarbituric acid reactive substances (TBARS), physicochemical and microbiological properties. The first phase results indicated that the highest inhibition was determined in Listeria monocyctogenes 472 regardless of tested Aloe vera extract doses and extraction methods (Tukey HSD, $P<0.05$ ). The highest Listeria monocyctogenes 472 levels reached was $0.38 \log _{10}$ $\mathrm{cfu} / \mathrm{g}$. The second phase results revealed that Aloe vera containing treatments of sausage had lower $\mathrm{pH}$ than others after storage (ANOVA, $P<0.05$ ). Dry matter, protein, fat and ash contents of sausage dough increased in all treatments after fermentation (ANOVA, $P<0.05$ ). After $30 \mathrm{~d}$ storage, 48 and $45 \%$ TBARS reductions were obtained in sausages with only nitrite and those with only Aloe vera extract compared to control respectively. The lowest TBARS (68\% reduction) were obtained in Aloe vera
\end{abstract}

Supplementary information The online version contains supplementary material available at https://doi.org/10.1007/s13197021-05183-5.

Gülden Başyiğit Kılıç

gkilic@mehmetakif.edu.tr

1 Department of Food Engineering, Engineering and Architecture Faculty, Mehmet Akif Ersoy University, Burdur, Turkey

2 Department of Food Engineering, Suleyman Demirel University, Isparta, Turkey extract and nitrite incorporated sausages (Tukey HSD, $P<0.05)$. Result showed that the use of Aloe vera extract and nitrite combination in sausage formulation is a useful approach to control lipid oxidation in the product.

Keywords Aloe vera $\cdot$ Safety $\cdot$ Quality $\cdot$ Sausage

\section{Introduction}

Microbial, chemical and enzymatic changes are important factors that limit the shelf life and safety of meat and meat products (Mhalla et al. 2017). Lipid oxidation is the most important chemical change that causes quality losses, especially during the storage of ready-to-eat meat products. As a result of lipid oxidation, undesirable color, flavor, odor and toxic compounds are formed in meat and meat products (Noor et al. 2018). One of the most commonly used methods in preventing or delaying the oxidation reaction is the use of antioxidants. Synthetic antioxidants such as butylated hydroxytoluene (BHT) butylated hydroxyanisole (BHA) and tertiary-butyhydroquinone (TBHQ) or natural antioxidants such as vitamin E, ascorbic acid and $\beta$-carotenes have been used for many years to control lipid oxidation. The use of synthetic antioxidants are questioned because of their toxic effects, a high cost and the consumer's health concerns (Mhalla et al. 2017). Therefore, while the use of synthetic antioxidants such as BHA and TBHQ is limited in some countries, they are prohibited in some other countries. In addition to the shelf life expectation of consumers, there are serious expectations from food manufacturers to increase food safety in order not to encounter foodborne diseases and viral infections like COVID-19 pandemic (Rizou et al.2020). In addition, the era of the COVID-19 pandemic created 
different aspects for food industry to consider such as the transmission of the disease through the food chain, food security, sustainability, and biofortification of foods with micronutrients to enhance the immune system (Galanakis et al. 2021; Galanakis, 2015). In this respect, non-thermal technologies has been reported to have ability to maintain the bioavailability of food components, improve their functional and technological properties, and increase the recovery yields from agricultural products (Galanakis, 2021). Furthermore, the post-pandemic food sector has the future expectations from food ingredients such as natural antioxidants to serve as health-promoting agents with possible antimicrobial functions, anti-inflammatory activities, and potential antiviral actions (Galanakis, 2020; Galanakis et al. 2020). The demands of consumers to prioritize the use of natural resources in increasing food quality and safety have directed the food industry to the area of natural antioxidants and antimicrobials. Therefore, searching natural antioxidants and antimicrobial sources have gained importance (Bondi et al. 2017).

Turkish dry fermented sausage is a dry, uncooked and cured fermented sausage produced from ground beef, beef fat, salt, sugar, nitrite/nitrate and various spices such as garlic, cumin, allspice, black and red pepper. It has been produced and consumed around the Balkans, Middle East and Europe for decades. Since it is fermented product, Turkish dry fermented sausage has a lots of similarities with some European sausages like chorizo, krakowska and kaminwurz regarding processing process and product characteristics. These products including Turkish dry fermented sausage are usually made from comminuted meat and fat, mixed with salt, curing agents, sugar and spices, incorporated with the lactic acid bacteria and filled into casings. All of these fermented sausages varies from country to country based on their differences on the proximate composition, the casing diameter, the animal species used for obtaining the raw meat material, the spices, seasonings and other non-meat ingredients used (Kilic 2009).

Aloe vera is a plant that has been used for centuries for its health, beauty and skin care properties. Clinical studies have revealed that the pharmacologically active substances of Aloe vera are concentrated in the sap and the gel of Aloe vera leaves (Surjushe et al. 2008). Many pharmacological properties such as antimicrobial, antioxidant, antidiabetic, antiallergic, hypoglycemic, gastroprotective, immune modulator, wound-healing effects have been attributed to Aloe vera (Lucini et al. 2012). Because of these pharmacological features, it is used in the production of a variety of commercial products. Research has shown that Aloe vera has a strong antioxidant property and inhibits lipid oxidation by significantly enhancing the activity of antioxidant enzymes such as glutathione-S-transferase, glutathione peroxidase, catalase and superoxide dismutase (Hu et al. 2003). Vitamins A, C, E, B12, choline and folic acid which are abundant in Aloe vera structure, have also important contribution to antioxidant properties of Aloe vera. In addition to its antioxidant properties, Aloe vera has antiviral, anti-inflammatory and antitumor properties (Surjushe et al. 2008). It has been stated that the antimicrobial activities of plants depend on tannins, saponins, phenolic components, essential oils and flavonoids found in their structures. Aloe vera includes free anthraquinones and their derivatives such as barbaloin, aloe-emodin-9-anthrone, isobarbaloin, the anthrone C-glycosides and chromones (Kumar et al. 2015). AV extracts were found to show antimicrobial effect against fungal strains such as Aspergillus niger and Candida albicans, and pathogenic microorganisms such as Staphylococcus aureus, Streptococcus pyogenes, Escherichia coli, Klebsiella pneumoniae, Salmonella Typhi, Pseudomonas aeruginosa, Helicobacter pylori, Propionibacterium acne, Shigella flexneri and Streptococcus pyogenes (Kumar et al. 2015; NejatzadehBarandozi 2013). Extracts made with alcohol showed stronger antibacterial and antifungal effects compared to aqueous extracts. Chatterjee et al. (2015) found that Aloe vera gel extract prepared with methanol has stronger antibacterial activity in Gram positive bacteria than Gram negative due to difference in cell wall composition.

Aloe vera has also gained great attention in the food industry and utilized as a functional ingredient in beverages, drinks, and dairy products such as ice cream. Research on the use of Aloe vera in meat and meat products is quite new and limited research is available on this subject. In these limited number of studies, Aloe vera has been used in chicken meat (Meena et al. 2019; Sari et al. 2017), low-fat meat emulsion (Kumar et al. 2017), low meat beef burgers (Soltanizadeh and Ghiasi-Esfahani 2015) and meat nuggets (Rajkumar et al. 2016) for different purposes such as improving the quality and shelf-life. Sari et al. (2017) showed that Aloe vera gel decreased cooking loss and fat absorption without adversly affecting the sensory properties in chicken meat during frying. Meena et al. (2019) also stated that Aloe vera gel extract can be used as an organic and natural preservative in the chicken meat. Improvement in cooking yield in nuggets was reported due to utilization of Aloe vera gel (Soltanizadeh and Ghiasi-Esfahani 2015; Rajkumar et al. 2016). Microorganisms frequently encountered in meat and meat products are E. coli, Salmonella spp, Listeria monocytogenes, S. aureus, Yersinia enterocolitica, Clostridium perfringens and Clostridium botulinum (Hansen et al. 2016). Increasing the quality and safety, controlling lipid oxidation and the growth of spoilage and pathogenic microorganisms in meat and meat products via using natural additives is requested by consumers and the meat industry. 
The present study intended, in the first phase, to determine in vitro inhibitory effect of Aloe vera extract on Stapylococcus aureus 25,923, S. aureus 43,300, L. monocyctogenes 472 , L. monocyctogenes 02,028, E. coli O157:H7 ATTC 35,150, Salmonella spp. 14,028, Salmonella spp. 700,408 ve Pseudomonas flouroscens 13,525. Then, the study aimed to investigate the effects of Aloe vera extract usage in the sausage production on lipid oxidation inhibition, the quality and microbiological characteristics of the sausages during fermentation and storage in the second phase in order to meet the consumers' demands for healthy food.

\section{Materials and methods}

\section{Bacterial strains and reagents}

S. aureus 25,923, S. aureus 43,300, L. monocytogenes 472, L. monocytogenes 02,028 , E. coli O157: H7 ATTC 35,150, Salmonella spp. 14,028, Salmonella spp. 700,408 and $P$. fluorescens 13,525 were selected from the stocks available in the Department of Food Engineering at Burdur Mehmet Akif Ersoy University. Starter culture (Frutoram, Savory Solutions, Gewürzmüller, Nesse) used in sausage production was provided from Etol Aroma ve Baharat Gida Urunleri San ve Tic. A.Ş., Izmit, Turkey. Aloe vera plant used in the research was obtained from Nisa Fidancilik, Yalova, Turkey. A $24 \mathrm{~h}$ post mortem beef (Longissimus thoracis et lumborum) and beef fat purchased from a local meat company were used. Other non-meat ingredients used for sausage processing were provided from local suppliers in Isparta, Turkey.

\section{Extracts of Aloe vera}

Four different methods have been used to obtain extracts of Aloe vera (Table 1). Ethanol was used as solvent for Aloe vera gel (Treatment I) and the whole Aloe vera plant (Treatment II) to have Aloe vera extract. Ten grams of sample were macerated for $48 \mathrm{~h}$ in $80 \%$ ethanol at room temperature in the dark environment. Then, the samples were evaporated under vacuum at $40{ }^{\circ} \mathrm{C}$ until the solvent was removed (Rajkumar et al., 2016). In treatment III, Aloe vera gel was dried at $80{ }^{\circ} \mathrm{C}$ for $48 \mathrm{~h}$. Then, $100 \mathrm{ml}$ of deionized water was added to $10 \mathrm{ml}$ of dried Aloe vera gel. After storing the mixture for $48 \mathrm{~h}$ at room temperature in a dark environment, it was filtered through a $0.45 \mu \mathrm{m}$ filter. In the group IV, Aloe vera plant was cut and dried at $80^{\circ} \mathrm{C}$ for $48 \mathrm{~h}$. Dried Aloe vera (10 g) was macerated for $48 \mathrm{~h}$ in $80 \%$ ethanol at room temperature in dark environment. The samples were evaporated under vacuum at $40{ }^{\circ} \mathrm{C}$ until the solvent was removed (Karpagam and Devaraj 2011).

\section{Determination of minimum inhibitory concentration (MIC) of Aloe vera extracts}

In order to determine the minimum inhibitory concentration (MIC) of Aloe vera extracts, bacterial densities were read using a microplate reader (Epoch Microplate Spectrophotometer, BioTek Instruments, Winooski, VT) at the MAKU Science and Technology Center. The MIC values of Aloe vera extracts were determined with 96-well microplates by a microdilution method reported by Goudarzi et al. (2015). The density of the pathogenic microorganisms used was adjusted to $0.5 \mathrm{McFarland}$ Latex Standards. Aloe vera concentrations were set at 25, 50, 100, 200, 400 and $800 \mu \mathrm{g} / \mathrm{ml}$ in Caso broth. Pathogenic microorganisms were then inoculated into the media containing these concentrations and microplates were incubated at $37{ }^{\circ} \mathrm{C}$ for $48 \mathrm{~h}$. Bacterial density measurements using a microplate reader were replicated four times.

\section{Sausage manufacturing}

Following the results of phase 1 which showed that differences in the extraction methods were not a factor affecting antimicrobial capabilities of Aloe vera extract on each individual tested microorganism, Aloe vera extract used in sausage processing was obtained by ethanol extraction of the whole Aloe vera plant dried at $80^{\circ} \mathrm{C}$ (group IV in the first phase) which is commonly used extraction method. The meat used in the production of sausage was ground and the sausage production was carried out as stated in Özer et al. (2016). Ground meat was divided into four equal amounts depending on experimental groups and sausage groups were prepared according to tested formulations (Table 1). Within the scope of the research, a control and three different experimental setups were created. The control sausages (C) were produced without Aloe vera and sodium nitrite. The other experimental groups were produced with $156 \mathrm{ppm}$ sodium nitrite (SN) or $1 \%$ Aloe vera (AV) or $1 \%$ Aloe vera plus $156 \mathrm{ppm}$ sodium nitrite (SNAV). Regardless of experimental groups, all sausage formulations also contained lean beef, beef fat, sodium chloride and spice mix (Table 1). After preparing the batches of raw sausage dough, they were stored in the refrigerator for 2-3 h. After that, the sausage dough belonging to each group was stuffed into $40 \mathrm{~mm}$ diameter collagen casings. The sausages were taken to the fermentation cabinet and stored at $25{ }^{\circ} \mathrm{C}$ and $95 \%$ humidity for 10 $\mathrm{d}$ for fermentation. At the end of the $10 \mathrm{~d}$ fermentation, sausages were vacuum packaged and stored at $4{ }^{\circ} \mathrm{C}$ for 20 d. The sausage processing was carried out on separate processing days for each of three replications. A total of 147 sausages were produced and three measurements were taken for each tested parameter per replication. 
Table 1 Experimental design to obtain extracts of Aloe vera and preparation of sausages, and sausage formulation

\begin{tabular}{|c|c|}
\hline Groups & Extraction method \\
\hline I & Extraction of Aloe vera gel with ethanol \\
\hline II & Extraction of the whole Aloe vera plant with ethanol \\
\hline III & Water extraction of Aloe vera gel dried at $80^{\circ} \mathrm{C}$ \\
\hline IV & Ethanol extraction of the whole Aloe vera plant dried at $80^{\circ} \mathrm{C}$ \\
\hline Treatments & Added Aloe vera and sodium nitrite \\
\hline $\mathrm{C}$ & Control, no Aloe vera and sodium nitrite \\
\hline SN & $156 \mathrm{ppm}$ sodium nitrite \\
\hline $\mathrm{AV}$ & $1 \%$ Aloe vera \\
\hline SNAV & $1 \%$ Aloe vera $+156 \mathrm{ppm}$ sodium nitrite \\
\hline Ingredients & Amount $(\%)$ \\
\hline Meat & 79.67 \\
\hline Fat & 15.73 \\
\hline Starter Culture Mix & 0.025 \\
\hline Salt & 1.9 \\
\hline Sucrose & 0.4 \\
\hline Garlic & 0.08 \\
\hline Red pepper & 0.06 \\
\hline Black pepper & 0.5 \\
\hline Cumin & 0.9 \\
\hline Allspice & 0.25 \\
\hline
\end{tabular}

\section{Physicochemical composition}

$\mathrm{pH}$ measurements in sausage samples were measured using a portable $\mathrm{pH}$ meter (HI 9024, Hanna Instruments, Germany) connected to a spear type electrode (FC 200, Hanna Instruments, Germany). The device was calibrated with $\mathrm{pH}$ 4.0-7.0 buffer solutions before $\mathrm{pH}$ measurements. CIE L *, $\mathrm{a} *, \mathrm{~b} *$ color values were determined by using Precise Color Reader TCR 200 color measurement device (Hullberg and Lundström 2004). The color measurements were performed at $10^{\circ}$ standard observer, D65 illuminant, 8-mm-diameter circle (measurement area approximately $0.5 \mathrm{~cm}^{2}$ ) and the specular component included (SCI) mode. Before the measurements, the device was calibrated using its own calibration plate $\left(\mathrm{D} 65, \mathrm{~L}^{*}=97.79, \mathrm{a}^{*}=-0.11\right.$, $b^{*}=2.69$ ). The water activity values of the samples were determined by using a water activity device (Novasina AG Lab Swift, Switzerland). Dry matter, protein, fat and ash contents were determined according to AOAC (2012). pH, CIE $\mathrm{L} *, \mathrm{a} *, \mathrm{~b} *$ color and water activity analyzes were carried out in certain time intervals $(0,5,10,15$ and $30 \mathrm{~d})$, whereas protein, fat ash and dry matter analyzes were made immediately after the production and the fermentation stages.

\section{TBARS analysis}

In order to follow lipid oxidation in sausage samples, TBARS analysis was performed according to the method described by Kılıç et al. (2018). A spectrophotometer (UV/ VIS Spectrometer T80, PG instruments, UK) with a spectral range of 190-1100 $\mathrm{nm}$ was used to determine TBARS values in sasauge samples by recording the absorbance at $532 \mathrm{~nm}$. A standard curve was prepared with 1,1,3,3-tetraethoxypropane in each sampling occasion. TBARS measurements were carried out on days $0,5,10,15$ and 30 . TBARS results are expressed as $\mu$ mol MDA/kg TBARS in sausage.

\section{Texture profile analysis}

Sausages were sliced into about $10 \mathrm{~mm}$ height cylindrical samples, covered with stretch film, and held at $23{ }^{\circ} \mathrm{C}$ for equilibration to room temperature.Texture measurements were performed by using a TA-XT2 Plus Texture Analyzer 
(Stable micro Systems, Godalming, England). Analysis conditions for texture measurements; probe thickness: $36 \mathrm{~mm}$, load cell: $50 \mathrm{~kg}$, sample thickness: $0.5 \mathrm{~cm}$, penetration $0.35 \mathrm{~mm}$ ( $70 \%$ compression), probe speed before and after the test: $5 \mathrm{~mm} / \mathrm{sec}$ and probe speed during the test: $2 \mathrm{~mm} / \mathrm{sec}$. As a result of texture profile analysis (TPA), hardness (g), adhesiveness $(\mathrm{g} \cdot \mathrm{s})$, springiness, cohesiveness, gumminess, chewiness, and resilience parameters were determined (Kılıç et al. 2018). TPA analysis was performed on three different sausages (one slice per sausage and one reading per slice) from each treatment. Texture measurements were carried out on days $0,10,15$ and 30 .

\section{Microbiological analysis}

Aseptically taken $10 \mathrm{~g}$ of sausage was added into $90 \mathrm{ml}$ sterile buffered peptone water and homogenized with a stomacher at room temperature. After preparation of decimal dilutions in buffered peptone water, $0.1 \mathrm{ml}$ samples in duplicate were spread on appropriate mediums. In the study, the total mesophilic aerob bacteria (TMAB) in Plate Count Agar (PCA) (Merck, Darmstadt, Germany), total lactic acid bacteria (LAB) in De Man, Rogosa and Sharpe agar (MRS) (Merck, Darmstadt, Germany), total coliform in Eosin Methylene Blue agar (EMB) (Merck, Darmstadt, Germany), and the number of yeast and mold in Potato Dextose Agar (PDA) (Merck, Darmstadt, Germany) mediums were determined. MRS and EMB agar mediums were incubated for $48 \mathrm{~h}$ at $37^{\circ} \mathrm{C}$, whereas PCA and PDA mediums were incubated at $30{ }^{\circ} \mathrm{C}$ for $48 \mathrm{~h}$ and at $25^{\circ} \mathrm{C}$ for $5 \mathrm{~d}$, respectively. Microbiological analyses were carried out in triplicate (three times) for each treatment at each measurement day $(0,5,10,15$ and 30).

\section{Statistical analysis}

In the study, the entire experiments were repeated three times and analyses were also performed in triplicate (three times) for each treatment. For the first phase (MIC experiment), the experimental design included four extraction methods and six Aloe vera doses as a factorial arrangement with all main effects and interactions associated with the independent variable factors (extraction method and Aloe vera dose). The dependent variables for MIC experiment were the counts of tested pathogens. The experimental design for the second phase (Sausage experiment) was completely randomized design with four treatments which included control (no Aloe vera and sodium nitrite) and three groups with sodium nitrite or Aloe vera or combination of both. Data collected for chemical composition (proximate composition), physicochemical properties $(\mathrm{pH}$, TBARS and color), microbiological and textural properties of sausages were analyzed by generalized linear mixed model (GLMM) procedure to determine significant difference during all processing stages (sausage dough, fermentation and storage). In the statistical design, treatments and processing stages (sausage dough, fermentation and storage) were assigned as fixed effects and replications as a random effect. Significant differences between the average means were tested using the Tukey multiple comparison test. Differences among mean values were considered significant when $P<0.05$. The results were expressed as mean values with standard errors of the mean (SEM) from the three replications. The results were analyzed statistically using Minitab 17.3.1 (Minitab Statistical Software, USA). The results of the dependent variables (MIC, proximate composition, $\mathrm{pH}$, color, TBARS, microbiological and textural properties) with main effects and up to two way interactions are presented.

\section{Results and discussion}

\section{MIC results}

Results indicated that the difference in the extraction methods and tested extract doses generally did not affect antimicrobial capabilities of Aloe vera extract on each individual tested microorganism (Table 2). Hovewer, as far as comparison of the inhibition levels achieved by Aloe vera extract on all 8 tested microorganisims (P. fluorescens 13,525, L. monocytogenes 472, L. monocytogenes 02,028, Salmonella spp. 14,028, Salmonella spp. 700,408, E. coli O157:H7 ATTC 35,150, S. aureus 25,923 and S. aureus 43,300) are concerned, the highest inhibition was determined in L. monocytogenes 472 strain followed by $L$. monocytogenes 02,028 strain in all extraction methods and all tested Aloe vera extract doses (Tukey HSD, $P<0.05$ ). The highest abundance levels reached were 0.38 and 0.74 $\log _{10} \mathrm{cfu} / \mathrm{g}$ for Listeria monocyctogenes 472 and $L$. monocytogenes 02,028 respectively. Aloe vera extract prepared in group I showed the lowest inhibition activity on Salmonella spp. 700,408, S. aureus 25,923 and E. coli O157: H7 ATTC 35,150 (Tukey HSD, $P<0.05$ ). Salmonella spp. 700,408, S. aureus 25,923 and E. coli O157: H7 ATTC 35,150 counts were 1.51, 1.39 and $1.33 \log _{10}$ $\mathrm{cfu} / \mathrm{g}$ respectively. The least affected pathogens in group II were Salmonella spp. 700,408 with growth level of 1.49 $\log _{10} \mathrm{cfu} / \mathrm{g}$, E. coli O157:H7 ATTC 35,150 with growth level of $1.39 \log _{10} \mathrm{cfu} / \mathrm{g}$ and $S$. aureus 25,923 with growth level of $1.22 \log _{10} \mathrm{cfu} / \mathrm{g}$ (Tukey HSD, $P<0.05$ ). The weakest inhibition in groups III and IV was obtained on $S$. aureus 25,923, E. coli O157:H7 ATTC 35,150 and Salmonella spp. 700,408 (Tukey HSD, $P<0.05$ ). Thus, MIC results indicated that $L$. monocytogenes 472 and $L$. 
monocytogenes 02,028 were the most affected strains, whereas Salmonella spp. 700,408, S. aureus 25,923 and E. coli O157: H7 ATTC 35,150 were the least affected strains by Aloe vera extract regardless of extract dose and extraction method (Tukey HSD, $P<0.05$ ). Some of previous studies also demonstrated the antimicrobial effectiveness of Aloe vera extract or gel obtained by different extraction methods on other microorganisms. NejatzadehBarandozi (2013), extracted Aloe vera gel with distilled water, ethanol and acetone solutions and investigated antimicrobial effects of these Aloe vera extracts on $S$. aureus, S. pyogenes, $P$. aeruginosa and E. coli. Authors reported that the highest antibacterial activity was determined in Aloe vera extracted with ethanol and a higher inhibition was obtained on $S$. pyogenes and $P$. aeroginosa compared to $S$. aureus and E. coli. Gharibi et al. (2015) investigated the antimicrobial activities of Aloe vera gel, boiled Aloe vera leaves, boiled Aloe vera gel and distilled Aloe vera extract against $S$. aureus, $K$. pneumonia and $P$. aeruginosa. Their study demonstrated that Aloe vera extract prepared by distillation showed the highest antimicrobial effect on four bacterial strains. These findings have been linked to the activation of some antimicrobial agents after distillation. The same study showed that Aloe vera gel and boiled Aloe vera leaves were only effective on S. aureus. Hayat et al. (2016) investigated in vitro antimicrobial activity of extract of Aloe vera leaves against Erwinia carotovora, E. coli, K. pneumoniae, Salmonella Typhi, Bacillus subtilis, Bacillus cereus, S. aureus and $C$. albicans and found that the highest inhibition was determined against $C$. albicans. Their results supported that Aloe vera extracts can be used against both bacterial and fungal pathogens.

\section{Physicochemical properties of sausages}

The $\mathrm{pH}$ values in the sausage doughs ranged between 5.94 and 6.13 (Table 3). A 2-way interaction between treatments and processing stages was found regarding $\mathrm{pH}$ values of experimental sausage treatments (ANOVA, $P=0.008$ ). This interaction showed that SNAV treatment had lower $\mathrm{pH}$ than control and SN on day 15 in terms of $\mathrm{pH}$ (Tukey HSD, $P<0.05)$. The same interaction showed that a decrease in $\mathrm{pH}$ was determined in all treatments (except control) by $5 \mathrm{~d}$ (Tukey HSD, $P<0.05$ ) and $\mathrm{pH}$ values were quite stable during rest of the processing stages and storage periods. However, $\mathrm{pH}$ values in control decreased (ANOVA, $P<0.05$ ) until the end of the fermentation (day 10 ), then started to increase (ANOVA, $P<0.05$ ) until day 15 and did not change during rest of the storage. Soltanizadeh and Ghiasi-Esfahani (2015) indicated that Aloe vera reduced the $\mathrm{pH}$ of beef burgers due to its acidic $\mathrm{pH}$ of 4.1 . Kim et al. (2019) also reported pH lowering effects in frankfurter formulated with combination of kojac gel and Aloe vera powder. In addition, effects of fermentation on the $\mathrm{pH}$ of sausages are well demonstrated. Kameník et al. (2012) stated that initial $\mathrm{pH}$ in vacuum packed dry fermented sausage (Poličan) dropped from 5.93 to 5.04 after

Table 2 Results of Aloe vera extraction method*type of microorganism and Aloe vera dose*type of microorganism interactions for microbial inhibition values $\left(\log _{10} \mathrm{cfu} / \mathrm{ml}\right)$

\begin{tabular}{|c|c|c|c|c|c|c|c|c|c|}
\hline & & $\begin{array}{l}P . \\
\text { fluorescens }\end{array}$ & $\begin{array}{l}L . \\
\text { monocytogenes } \\
02,028\end{array}$ & $\begin{array}{l}L . \\
\text { monocytogenes } \\
472\end{array}$ & $\begin{array}{l}\text { Salmonella } \\
\text { spp. } 14,028\end{array}$ & $\begin{array}{l}\text { Salmonella } \\
\text { spp. } 700,408\end{array}$ & $\begin{array}{l}\text { E. coli } \\
\text { O157:H7 }\end{array}$ & $\begin{array}{l}\text { S. aureus } \\
43,300\end{array}$ & $\begin{array}{l}\text { S. aureus } \\
25,923\end{array}$ \\
\hline \multirow{5}{*}{$\begin{array}{c}\text { Extraction } \\
\text { method }\end{array}$} & I & $1.11^{\mathrm{fgh}}$ & $0.58^{\mathrm{j}}$ & $0.35^{\mathrm{k}}$ & $1.02^{\mathrm{ghi}}$ & $1.51^{\mathrm{a}}$ & $1.33^{\mathrm{bcd}}$ & $1.06^{\mathrm{ghi}}$ & $1.39^{\mathrm{abc}}$ \\
\hline & II & $1.02^{\mathrm{ghi}}$ & $0.68^{\mathrm{j}}$ & $0.33^{\mathrm{k}}$ & $1.05^{\mathrm{ghi}}$ & $1.49^{\mathrm{a}}$ & $1.39^{\mathrm{abc}}$ & $1.01^{\text {ghi }}$ & $1.22^{\mathrm{def}}$ \\
\hline & III & $1.07^{\text {ghi }}$ & $0.71^{\mathrm{j}}$ & $0.38^{\mathrm{k}}$ & $0.98^{\text {hi }}$ & $1.41^{\mathrm{abc}}$ & $1.29^{\mathrm{bcd}}$ & $1.07^{\text {ghi }}$ & $1.33^{\mathrm{bcd}}$ \\
\hline & IV & $1.05^{\mathrm{ghi}}$ & $0.68^{\mathrm{j}}$ & $0.32^{\mathrm{k}}$ & $0.95^{\mathrm{i}}$ & $1.43^{\mathrm{ab}}$ & $1.33^{\mathrm{bcd}}$ & $1.13^{\text {efg }}$ & $1.26^{\text {cde }}$ \\
\hline & SEM & 0.068 & & & & & & & \\
\hline \multirow{7}{*}{$\begin{array}{l}\text { Aloe vera } \\
\text { dose }\end{array}$} & 800 & $1.14^{\mathrm{FGHIJ}}$ & $0.74^{\mathrm{L}}$ & $0.36^{\mathrm{NO}}$ & $0.93^{\mathrm{K}}$ & $1.41^{\mathrm{ABC}}$ & $1.27^{\mathrm{CDEF}}$ & $1.19^{\mathrm{DEFGH}}$ & $1.34^{\mathrm{ABCDE}}$ \\
\hline & 400 & $1.08^{\mathrm{GHIJK}}$ & $0.54^{\mathrm{MN}}$ & $0.32^{\mathrm{O}}$ & $1.00^{\mathrm{IJK}}$ & $1.48^{\mathrm{A}}$ & $1.36^{\mathrm{ABCDE}}$ & $0.96^{\mathrm{JK}}$ & $1.28^{\mathrm{BCDEF}}$ \\
\hline & 200 & $1.06^{\mathrm{HIJK}}$ & $0.70^{\mathrm{LM}}$ & $0.31^{\mathrm{O}}$ & $1.03^{\mathrm{HIJK}}$ & $1.47^{\mathrm{A}}$ & $1.34^{\mathrm{ABCDE}}$ & $1.02^{\mathrm{HIJK}}$ & $1.26^{\mathrm{CDEFG}}$ \\
\hline & 100 & $1.03^{\mathrm{HIJK}}$ & $0.68^{\mathrm{LM}}$ & $0.31^{\mathrm{O}}$ & $1.06^{\mathrm{HIJK}}$ & $1.48^{\mathrm{A}}$ & $1.35^{\mathrm{ABCDE}}$ & $1.03^{\mathrm{HIJK}}$ & $1.25^{\mathrm{CDEFG}}$ \\
\hline & 50 & $1.03^{\mathrm{HIJK}}$ & $0.57^{\mathrm{LM}}$ & $0.38^{\mathrm{NO}}$ & $1.05^{\mathrm{HIJK}}$ & $1.47^{\mathrm{A}}$ & $1.37^{\mathrm{ABCD}}$ & $1.05^{\mathrm{HIJK}}$ & $1.27^{\mathrm{CDEF}}$ \\
\hline & 25 & $1.04^{\mathrm{HIJK}}$ & $0.73^{\mathrm{L}}$ & $0.38^{\mathrm{NO}}$ & $0.93^{\mathrm{K}}$ & $1.44^{\mathrm{ABC}}$ & $1.33^{\mathrm{ABCDE}}$ & $1.17^{\mathrm{EFGHI}}$ & $1.39^{\mathrm{ABC}}$ \\
\hline & SEM & 0.070 & & & & & & & \\
\hline
\end{tabular}

SEM standard error of the mean. All values are the mean of three replicates $(\mathrm{n}=9)$, I: Extraction of Aloe vera gel with ethanol, II: Extraction of the whole Aloe vera plant with ethanol, III: Water extraction of Aloe vera gel dried at $80{ }^{\circ} \mathrm{C}$, IV: Ethanol extraction of the whole Aloe vera plant dried at $80{ }^{\circ} \mathrm{C}$. Data obtained for all tested pathogens were analyzed separately from each other. ${ }^{\mathrm{a}-\mathrm{k}}$ Different letters within extraction method section are significantly different $(P<0.05)$. ${ }^{\mathrm{A}-\mathrm{O}}$ Different letters within Aloe vera dose section are significantly different $(P<0.05)$ 
the fermentation period. Seong et al. (2016) also determined that the $\mathrm{pH}$ values of fermented sausages produced with soy protein decreased to 5.0-5.1. Ju et al. (2016) reported a decrease in $\mathrm{pH}$ values of fermented pork sausages up to $21 \mathrm{~d}$ fermentation. This $\mathrm{pH}$ change has been linked to the microbial activity of LAB, which metabolizes sugar in meat to produce lactic acid (Ju et al. 2016).

The color values of the sausages are shown in Table 3. In terms of $\mathrm{L}^{*}$ (lightness) values, no significant differences were determined in the sausage dough among treatments. After fermentation and $20 \mathrm{~d}$ storage, $\mathrm{L}^{*}$ values decreased in all treatments (ANOVA, $P<0.05$ ). As a result of $20 \mathrm{~d}$ storage, the lowest $\mathrm{L}^{*}$ values were determined in SNAV (Tukey HSD, $P<0.05$ ), whereas, no significant differences were found among the other treatments regarding $L^{*}$. In terms of $\mathrm{a}^{*}$ (redness) values, it was found that the addition of Aloe vera to sausage formulation decreased a* values compared to control or sausages containing only sodium nitrite (Tukey HSD, $P<0.05$ ). As a result of $20 \mathrm{~d}$ storage, the effect of Aloe vera on a* values was not exist. Therefore, it was determined that the use of Aloe vera in sausage formulation did not cause a negative effect on $\mathrm{a}^{*}$ values. As a result of the storage period, differences among all treatments in terms of $\mathrm{a}^{*}$ were found to be insignificant. When the groups were evaluated in terms of $b^{*}$ (yellowness), it was determined that control generally had lower $b^{*}$ values compared to other treatments (Tukey HSD, $P<0.05)$. During fermentation and storage, changes in $b^{*}$ values were found to be insignificant in all treatments. After $20 \mathrm{~d}$ storage, no significant differences were found between treatments in terms of $b^{*}$ values. Previous studies stated that a reduction in the amount of oxymyoglobin and formation of nitrosomyoglobin during fermentation period in sausage manufacturing caused similar results in $\mathrm{L}^{*}, \mathrm{a}^{*}$ and $b^{*}$ values (Bozkurt and Bayram 2006).

Water activity results (Table 3) indicated that all experimental sausage doughs had water activity values ranging from 0.92 to 0.94 . A 2-way interaction between treatments and processing stages was exist regarding water activity values of sausage treatments (ANOVA, $P=0.001)$. Treatments and processing stages interaction demonstrated that there was a gradual decrease in water activity values in control and SN during $20 \mathrm{~d}$ storage (ANOVA, $P<0.05$ ), wherease water activity in AV and SNAV decreased until the end of fermentation and then stayed quite stable during the storage period. The water activity values in treatments ranged from 0.85 to 0.87 at the end of storage. A decrease in water activity in all treatments is thought to be associated with the $\mathrm{pH}$ decrease and drying during the fermentation process. When sausage doughs are compared, no water activity differences were determined among treatments. Treatments and processing stages interaction showed that AV and SNAV sausages had lower water activity compared to control at the end of the fermentation (Tukey HSD, $P<0.05$ ), however, this difference was not observed at the end of storage.

Proximate composition of sausages are presented in Table 4. The amount of dry matter obtained in all treatments increased after fermentation (ANOVA, $P<0.05$ ). The use of Aloe vera in the sausage formulation caused an increase in the dry matter percentage in sausages (Tukey HSD, $P<0.05$ ). Soltanizadeh and Ghiasi-Esfahani (2015) also indicated that substitution of texturized soy protein with $3 \%$ and $5 \%$ Aloe vera enhanced water holding capacity and moisture retention while cooking loss was reduced in low meat beef burger. Kim et al. (2019) also reported an increase in water holding capacity and a reduction in cooking loss in frankfurters formulated with kojac gel with Aloe vera powder. Protein, fat and ash percentages determined in sausage dough increased in all treatments as a result of fermentation (ANOVA, $P<0.05$ ). Our results are confirmed by Bozkurt and Bayram (2006) who stated that the incorporation of starter cultures stimulates water loss in sausages and increases percent protein, ash, and fat contents in sausages as a result of decreased moisture content during fermentation. The differences between treatments in terms of protein, fat and ash percentages in sausages were found to be non-significant. Degirmencioglu et al. (2006) reported 45\% moisture, $28 \%$ protein and $35 \%$ fat in fermented sausages. Öksüztepe et al. (2011) demonstrated that 100 commercial fermented sausage samples sold in Elazig, Turkey had pH 5.18, 38.75\% moisture, $35.22 \%$ fat and $21.92 \%$ protein contents. According to the Turkish sausage standards, Turkish sausages are allowed to have $\mathrm{pH} 4.7-5.4$, a maximum of $40 \%$ moisture, a fat content up to $30 \%$ for the first class and $40 \%$ for the second class and protein content up to $20 \%$ for the first class and up to $18 \%$ for the second class (TSE 2012). In that respect, fermented sausages produced within this study meet Turkish standars. It is also well demonstrated that fermentation process has effects on proximate compositon of sausages (Bozkurt and Bayram 2006). The use of starter culture in sausage processing decreases $\mathrm{pH}$ at values near the isoelectric point of muscle proteins during fermentation process. At $\mathrm{pH}$ near the isoelectric point, muscle proteins are denatured due to decreased $\mathrm{pH}$ and lose their capability of holding water which causes an increase in drying rate. Thus, a gradual decrease in moisture content facilitates the drying process in sausage during fermentation period (Jung et al. 2015).

\section{TBARS}

Even though products formed during lipolysis and lipid oxidation play an important role in development of flavor and structure of the final product, lipid oxidation is also one 
Table 3 Results of treatment* processing stages interaction for $\mathrm{pH}$, color $\left(\mathrm{L}^{*}, \mathrm{a}^{*}\right.$, and $\left.\mathrm{b}^{*}\right)$ and water activity of fermented sausages during production and storage period as affected by the addition of Aloe vera and sodium nitrite

\begin{tabular}{|c|c|c|c|c|c|c|}
\hline \multirow[t]{2}{*}{ Dependent variables } & \multirow[t]{2}{*}{ Treatments } & \multicolumn{2}{|c|}{ Sausage dough } & \multicolumn{2}{|c|}{ After fermentation process } & \multirow{2}{*}{$\begin{array}{l}\text { End of the storage period } \\
30 \mathrm{~d}\end{array}$} \\
\hline & & $0 \mathrm{~d}$ & $5 \mathrm{~d}$ & $10 \mathrm{~d}$ & $15 \mathrm{~d}$ & \\
\hline \multirow[t]{5}{*}{$\mathrm{pH}$} & $\mathrm{C}$ & $6.10^{\mathrm{a}}$ & $5.23^{\mathrm{def}}$ & $5.10^{\mathrm{fg}}$ & $5.34^{\text {cdef }}$ & $5.56^{\mathrm{cd}}$ \\
\hline & $\mathrm{SN}$ & $6.13^{\mathrm{a}}$ & $5.23^{\mathrm{def}}$ & $5.30^{\text {cdef }}$ & $5.55^{\mathrm{cde}}$ & $5.62^{\mathrm{bc}}$ \\
\hline & AV & $6.02^{\mathrm{a}}$ & $5.03^{\mathrm{fg}}$ & $5.22^{\mathrm{def}}$ & $5.19^{\mathrm{efg}}$ & $5.33^{\text {cdef }}$ \\
\hline & SNAV & $5.94^{\mathrm{ab}}$ & $4.98^{\mathrm{fg}}$ & $5.16^{\mathrm{fg}}$ & $4.85^{\mathrm{g}}$ & $5.32^{\text {cdef }}$ \\
\hline & SEM & 0.33 & & & & \\
\hline \multirow[t]{5}{*}{$\mathrm{L}^{*}$} & $\mathrm{C}$ & $41.03^{\mathrm{abc}}$ & $43.00^{\mathrm{ab}}$ & $44.24^{\mathrm{ab}}$ & $52.00^{\mathrm{a}}$ & $41.04^{\mathrm{abc}}$ \\
\hline & $\mathrm{SN}$ & $46.90^{\mathrm{ab}}$ & $43.04^{\mathrm{ab}}$ & $40.49^{\mathrm{abc}}$ & $47.02^{\mathrm{ab}}$ & $36.74^{\mathrm{bcd}}$ \\
\hline & $\mathrm{AV}$ & $42.23^{\mathrm{abc}}$ & $40.28^{\mathrm{abcd}}$ & $33.80^{\mathrm{bcd}}$ & $39.87^{\mathrm{abcd}}$ & $28.80^{\mathrm{cd}}$ \\
\hline & SNAV & $43.14^{\mathrm{ab}}$ & $39.67^{\mathrm{abcd}}$ & $37.77^{\mathrm{bcd}}$ & $43.22^{\mathrm{ab}}$ & $26.74^{\mathrm{d}}$ \\
\hline & SEM & 3.53 & & & & \\
\hline \multirow[t]{5}{*}{$a^{*}$} & C & $16.51^{\text {bcdefg }}$ & $20.50^{\text {abcde }}$ & $21.67^{\mathrm{abcd}}$ & $18.17^{\text {abcdef }}$ & $15.33^{\text {cdefg }}$ \\
\hline & SN & $10.39^{\text {ghi }}$ & $25.10^{\mathrm{a}}$ & $22.69^{\mathrm{ab}}$ & $22.14^{\mathrm{abc}}$ & $16.69^{\text {bcdefg }}$ \\
\hline & $\mathrm{AV}$ & $5.50^{\mathrm{hi}}$ & $13.19^{\mathrm{fg}}$ & $17.18^{\text {bcdefg }}$ & $10.41^{\text {ghi }}$ & $13.03^{\mathrm{fg}}$ \\
\hline & SNAV & $4.39^{\mathrm{i}}$ & $14.76^{\text {defg }}$ & $17.42^{\text {bcdefg }}$ & $11.47^{\text {fgh }}$ & $14.50^{\text {efg }}$ \\
\hline & SEM & 1.35 & & & & \\
\hline \multirow[t]{5}{*}{$b^{*}$} & $\mathrm{C}$ & $15.48^{\mathrm{d}}$ & $18.69^{\mathrm{bcd}}$ & $22.54^{\mathrm{bcd}}$ & $16.47^{\mathrm{cd}}$ & $20.79^{\mathrm{bcd}}$ \\
\hline & SN & $21.96^{\mathrm{bcd}}$ & $21.88^{\mathrm{bcd}}$ & $25.31^{\mathrm{bcd}}$ & $17.79^{\mathrm{cd}}$ & $17.78^{\mathrm{cd}}$ \\
\hline & $\mathrm{AV}$ & $33.80^{\mathrm{abc}}$ & $24.27^{\mathrm{bcd}}$ & $45.39^{\mathrm{a}}$ & $20.25^{\mathrm{bcd}}$ & $28.61^{\mathrm{abcd}}$ \\
\hline & SNAV & $31.08^{\mathrm{abcd}}$ & $27.91^{\mathrm{bcd}}$ & $35.81^{\mathrm{ab}}$ & $21.23^{\mathrm{bcd}}$ & $29.10^{\mathrm{abcd}}$ \\
\hline & SEM & 6.51 & & & & \\
\hline \multirow[t]{5}{*}{ Water activity } & $\mathrm{C}$ & $0.939^{\mathrm{a}}$ & N.D & $0.914^{\mathrm{bc}}$ & $0.892^{\mathrm{de}}$ & $0.862^{\mathrm{gh}}$ \\
\hline & SN & $0.933^{\mathrm{a}}$ & N.D & $0.907^{\mathrm{cd}}$ & $0.893^{\mathrm{de}}$ & $0.850^{\mathrm{h}}$ \\
\hline & $\mathrm{AV}$ & $0.922^{\mathrm{abc}}$ & N.D & $0.896^{\mathrm{de}}$ & $0.880^{\mathrm{ef}}$ & $0.864^{\mathrm{fgh}}$ \\
\hline & SNAV & $0.925^{\mathrm{ab}}$ & N.D & $0.897^{\mathrm{de}}$ & $0.886^{\mathrm{e}}$ & $0.868^{\mathrm{fg}}$ \\
\hline & SEM & 0.035 & & & & \\
\hline
\end{tabular}

$S E M$ standard error of the mean. All values are the mean of three replicates $(\mathrm{n}=9)$. Treatment abbreviations; $C$ no Aloe vera and sodium nitrite, SN 156 ppm sodium nitrite, AV 1\% Aloe vera, SNAV: $1 \%$ Aloe vera $+156 \mathrm{ppm}$ sodium nitrite. Different letters within both a column and line in each parameter are significantly different $(P<0.05)$. N.D.: Not determined

of the main causes of quality deterioration in fermented sausages. Lipolysis is the first step in the self-oxidation process of free fatty acids (Flores and Olivares 2014). Lipolysis formed by lipid breakdown of hydrolyzed fatty acids, especially unsaturated fatty acids, forms hydroperoxides during fermentation and storage. These compounds are broken down into volatile compounds such as hydrocarbons, aldehydes, alcohols, ketones and carboxylic acids that are responsible for the characteristic aroma. Besides flavor development in dried fermented sausages, oxidative reactions causes of quality deterioration. Dry fermented sausages are rich in polyunsaturated fatty acids, but these compounds cause rancid aroma and discolorations (Flores and Olivares 2014).

TBARS results of the experimental treatments are presented in Table 5. A 2-way interaction among treatments and processing stages affected TBARS values in sausages (ANOVA, $P<0.001$ ). TBARS values determined in sausage dough ranged from 1.54 to $2.06 \mu \mathrm{mol} / \mathrm{kg}$. Treatments and processing stages interaction revealed that a gradual increase in TBARS values was determined in all experimental treatments during fermentation and $20 \mathrm{~d}$ storage periods (ANOVA, $P<0.05$ ) except SNAV group where there was no significant TBARS difference among processing stages. At the end of storage, the same interaction showed that the highest (Tukey HSD, $P<0.05$ ) TBARS values were determined in control and lower TBARS values were found in sausage samples produced using only nitrite and in sausages produced using Aloe vera compared to control (Tukey HSD, $P<0.05$ ). A $48 \%$ and $45 \%$ TBARS reduction rates were achieved in $\mathrm{SN}$ and $\mathrm{AV}$ sausage treatments, respectively, compared to control. As a 
Table 4 Pooled mean results for proximate composition of sausages associated with effects of treatments and processing stages

\begin{tabular}{lll}
\hline Treatments & \multicolumn{2}{l}{ Processing stages } \\
\cline { 2 - 3 } & Sausage dough & After fermentation process \\
\hline Dry matter (\%) & & \\
C & $46.87^{\mathrm{d}}$ & $54.99^{\mathrm{b}}$ \\
SN & $48.25^{\mathrm{cd}}$ & $57.07^{\mathrm{a}}$ \\
AV & $49.90^{\mathrm{c}}$ & $57.39^{\mathrm{a}}$ \\
SNAV & $50.03^{\mathrm{c}}$ & $58.00^{\mathrm{a}}$ \\
SEM & 0.70 & \\
Protein $(\%)$ & & \\
C & $16.64^{\mathrm{c}}$ & $19.84^{\mathrm{b}}$ \\
SN & $16.93^{\mathrm{c}}$ & $20.62^{\mathrm{ab}}$ \\
AV & $18.18^{\mathrm{c}}$ & $20.79^{\mathrm{ab}}$ \\
SNAV & $18.12^{\mathrm{c}}$ & $21.47^{\mathrm{a}}$ \\
SEM & 1.15 & \\
Fat $(\%)$ & & \\
C & $25.93^{\mathrm{b}}$ & $30.97^{\mathrm{a}}$ \\
SN & $27.03^{\mathrm{b}}$ & $32.26^{\mathrm{a}}$ \\
AV & $26.91^{\mathrm{b}}$ & $32.13^{\mathrm{a}}$ \\
SNAV & $26.99^{\mathrm{b}}$ & $31.51^{\mathrm{a}}$ \\
SEM & 4.71 & $3.45^{\mathrm{ab}}$ \\
Ash $(\%)$ & $3.11^{\mathrm{a}}$ \\
C & $3.25^{\mathrm{a}-\mathrm{d}}$ & \\
SN & 0.09 & \\
AV & $3.15^{\mathrm{d}}$ & \\
SNAV & $3.21^{\mathrm{bcd}}$ & \\
SEM & $3.15^{\mathrm{ab}}$ \\
\hline
\end{tabular}

SEM standard error of the mean. All values are the mean of three replicates $(\mathrm{n}=9)$. Treatment abbreviations; $C$ no Aloe vera and sodium nitrite, $S N 156 \mathrm{ppm}$ sodium nitrite, $A V 1 \%$ Aloe vera, SNAV: $1 \%$ Aloe vera $+156 \mathrm{ppm}$ sodium nitrite. ${ }^{\mathrm{a}-\mathrm{d}}$ Different letters within both a column and line in each parameter are significantly different $(P<0.05)$

result of $20 \mathrm{~d}$ storage, the lowest TBARS were determined in SNAV sausage samples in which Aloe vera and nitrite were used in combination (Tukey HSD, $P<0.05$ ). Research results showed that the use of Aloe vera extract in combination with nitrite is a more effective method for limiting oxidation. TBARS values were decreased by $68 \%$ in SNAV sausages compared to control. This result shows that the use of Aloe vera extract and nitrite combination in the sausage formulation is a useful approach for retarding lipid oxidation in the product. But treatments and processing stages interaction also demonstrated that this pattern regarding TBARS differences found among the experimental treatments at the end of $20 \mathrm{~d}$ storage was not exist during the first $10 \mathrm{~d}$ of sausage processing stages. Kumar et al. (2017) stated that Aloe gel addition into low- fat meat emulsion formulation resulted in more uniform emulsion matrix as a results of improved emulsification ability of meat proteins, and a higher oxidative stability in low-fat meat emulsion samples. Thus, authors suggested the addition of Aloe gel during manufacturing of emulsiontype meat products. Soltanizadeh and Ghiasi-Esfahani (2015) demonstrated that 3\% and 5\% Aloe vera incorporation in beef burger formulation retarded the lipid oxidation during the $7 \mathrm{~d}$ storage. Furthermore, Hu et al. (2003) found equal or even superior antioxidant capability of Aloe vera extract compared to BHT and $\alpha$-tocopherol.

\section{Texture analysis}

In terms of hardness, adhesiveness, springiness, cohesiveness, chewiness, gumminess and resilience values, no difference was found among all experimental treatments in sausage doughs and sausages after fermentation and storage (data is not presented). As result of drying, the hardness, adhesiveness, gummines and chewiness values increased (ANOVA, $P<0.05$ ) gradually in all experimental treatments during the fermentation process and remained quite stable during storage period. On the other hand, springiness, cohesiveness and resilience values did not change considerably in all experimental treatments during fermentation and storage periods. In this respect, Soltanizadeh and Ghiasi-Esfahani (2015) reported that substitution of texturized soy protein with of $3 \%$ and $5 \%$ Aloe vera improved textural properties in low meat beef burger. On the other hand, Kumar et al. (2017) indicated that incorporation of Aloe vera in the meat emulsion formulation had resulted in the reduction of hardness and chewiness values. Kim et al. (2019) also indicated that using a combination of kojac gel with Aloe vera powder in frankfurter formulation resulted in a reduction in hardness, springiness and gumminess properties. Furthermore, Kianiani et al. (2019) reported a reduction in hardness, adhesiveness and gumminess characteristics in German sausage produced with Aloe vera gel.

\section{Microbiological analysis}

Microbiological analysis results are presented in Table 6 . TMAB count in sausage doughs varied between $6.27 \log _{10}$ $\mathrm{cfu} / \mathrm{g}$ and $6.58 \log _{10} \mathrm{cfu} / \mathrm{g}$ among the experimental treatments. TMAB count in AV was lower than those determined in control (Tukey HSD, $P<0.05$ ). TMAB count decreased as a result of $5 \mathrm{~d}$ fermentation in all experimental treatments and then it gradually increased until the end of storage and reached its initial number determined in sausage dough (ANOVA, $P<0.05$ ).

The population of LAB obtained in sausage doughs varied between $5.85 \log _{10} \mathrm{cfu} / \mathrm{g}$ and $6.18 \log _{10} \mathrm{cfu} / \mathrm{g}$. No 
Table 5 Results of treatments*processing stages interaction for TBARS levels $(\mu \mathrm{mol} / \mathrm{kg})$ of fermented sausages

\begin{tabular}{|c|c|c|c|c|c|}
\hline \multirow[t]{2}{*}{ Treatments } & \multicolumn{2}{|c|}{ Sausage dough } & \multicolumn{2}{|c|}{ After fermentation process } & \multirow{2}{*}{$\begin{array}{l}\text { End of the storage period } \\
30 \mathrm{~d}\end{array}$} \\
\hline & $0 \mathrm{~d}$ & $5 \mathrm{~d}$ & $10 \mathrm{~d}$ & $15 \mathrm{~d}$ & \\
\hline $\mathrm{C}$ & $1.61^{\mathrm{f}}$ & $2.20^{\mathrm{def}}$ & $3.83^{\mathrm{d}}$ & $6.21^{\mathrm{bc}}$ & $11.89^{\mathrm{a}}$ \\
\hline $\mathrm{SN}$ & $1.54^{\mathrm{f}}$ & $2.18^{\mathrm{def}}$ & $2.50^{\mathrm{def}}$ & $2.79^{\mathrm{def}}$ & $6.24^{\mathrm{bc}}$ \\
\hline $\mathrm{AV}$ & $1.70^{\mathrm{ef}}$ & $2.68^{\mathrm{def}}$ & $3.95^{\mathrm{d}}$ & $4.13^{\mathrm{cd}}$ & $6.59^{\mathrm{b}}$ \\
\hline SNAV & $2.06^{\mathrm{def}}$ & $2.80^{\mathrm{def}}$ & $3.39^{\mathrm{def}}$ & $3.50^{\mathrm{def}}$ & $3.79^{\mathrm{de}}$ \\
\hline SEM & 0.43 & & & & \\
\hline
\end{tabular}

$S E M$ standard error of the mean. All values are the mean of three replicates $(\mathrm{n}=9)$. Treatment abbreviations; $C$ no Aloe vera and sodium nitrite, SN $156 \mathrm{ppm}$ sodium nitrite, AV 1\% Aloe vera, SNAV $1 \%$ Aloe vera $+156 \mathrm{ppm}$ sodium nitrite. ${ }^{\mathrm{a}-\mathrm{f}}$ Means within a dependent valriable with unlike letters are significantly different $(P<0.05)$ significant difference was found among all experimental treatments. In general, after fermentation and $20 \mathrm{~d}$ storage, there was a decrease in $\mathrm{LAB}$ counts in all sausages (ANOVA, $P<0.05$ ). However, after $20 \mathrm{~d}$ storage, no differences in LAB counts were determined among all treatments. Thus, the applications of nitrite or Aloe vera extract or combination of Aloe vera extract and nitrite had no effect on LAB population. Hammes et al. (2008) stated that the number of lactobacilli in fermented sausage ranged from 8 to $9 \log _{10} \mathrm{cfu} / \mathrm{g}$. Lactobacillus sakei, L. plantarum and L. curvatus are generally the most isolated species from fermented sausages. An increase in the number of LAB in sausage prepared with soy sauce was reported during fermentation period and researchers stated that the LAB population reached about $7 \log _{10} \mathrm{cfu} / \mathrm{g}$ on the 5 th day of fermentation (Seong et al. 2016). Toldrá et al. (2014) showed that LAB counts increased to 7-8 $\log \mathrm{cfu} / \mathrm{g}$ at the first $24-36 \mathrm{~h}$ of meat fermentation and remained stable during the rest of fermentation and storage period.

Although dry or semi-dry fermented sausages are considered as a reliable products due to low $\mathrm{pH}$ and low water activity, some pathogens may survive or even increase in these products. Studies have reported that E. coli, S. Typhimurium, S. aureus and L. monocytogenes as well as C. botulinum created potential microbiological risks for consumers in dry or semi-dry fermented sausages (Holck et al. 2017). Fermentation process itself has been reported to reduce L. monocytogenes by about $1 \log _{10} \mathrm{cfu} / \mathrm{g}$ (Kang and Fung, 2000). Despite obstacles such as low pH, low water activity or high salt content, it has been stated that Listeria maintains its vitality and may develop in fermented sausages (Colak et al. 2007).

The total number of yeast and mold determined in the sausage dough varied between $5.19 \log _{10} \mathrm{cfu} / \mathrm{g}$ and 5.32 $\log _{10} \mathrm{cfu} / \mathrm{g}$, whereas yeast and mold count in the sausage samples ranged from 4.45 to $4.91 \log _{10} \mathrm{cfu} / \mathrm{g}$ after fermentation and from 4.65 to $5.08 \log _{10} \mathrm{cfu} / \mathrm{g}$ after storage period. There was no difference among treatments in terms of total yeast and mold count in sausage doughs and sausage samples after fermentation and storage period.

As far as coliform bacteria are concerned, SN, AV and SNAV treatments had lower coliform bacteria compared to control (Tukey HSD, $P<0.05$ ). However, no difference was found among these three treatments regarding coliform bacteria. Coliform bacteria count did not show significant change during sausage processing stages.

\section{Conclusion}

The present study indicated that Aloe vera extracts showed inhibitory effect on in vitro growth of $S$. aureus 25,923, S. aureus 43,300, L. monocytogenes 472, L. monocytogenes 02,028, E. coli O157:H7 ATTC 35,150, Salmonella spp. 14,028, Salmonella spp. 700,408 ve P. fluorescens 13,525 regardles of tested Aloe vera extract doses and extraction methods. The highest inhibition was determined in $L$. monocyctogenes 472 strain in all tested Aloe vera extract doses and extraction methods. On the other hand, Salmonella spp. 700,408, S. aureus 25,923 and E. coli O157: H7 ATTC 35,150 were the least affected pathogens. The highest Listeria monocyctogenes 472 levels reached was $0.38 \log _{10} \mathrm{cfu} / \mathrm{g}$, whereas highest growth levels obtained for Salmonella spp. 700,408, S. aureus 25,923 and E. coli O157: H7 ATTC 35,150 were 1.51, 1.39 and $1.39 \log 10$ cfu/g, respectively, regardless of differences in tested Aloe vera extract doses and applied extraction methods. As far as sausages are concerned, no microbiological difference was found between sausage treatments. At the end of storage, a lower TMAB was detected in the AV group compared to control. It was determined that there was no significant difference between the groups in LAB numbers. While the highest TBARS value was obtained in control, a lower TBARS values were detected in SN and AV sausages. The lowest TBARS values were determined in SNAV sausages. A 48, 45 and $68 \%$ TBARS reduction rates were achieved in SN, AV and SNAV sausage treatments, 
Table 6 Pooled mean results for microbial properties $\left(\log _{10} \mathrm{cfu} / \mathrm{g}\right.$ sausage) of fermented sausages according to effects of treatments and processing stages

\begin{tabular}{|c|c|c|c|c|c|c|}
\hline \multirow[t]{2}{*}{ Dependent variables } & \multirow[t]{2}{*}{ Treatments } & \multicolumn{2}{|c|}{ Sausage dough } & \multicolumn{2}{|c|}{ After fermentation process } & \multirow{2}{*}{$\begin{array}{l}\text { End of the storage period } \\
30 \mathrm{~d}\end{array}$} \\
\hline & & $0 \mathrm{~d}$ & $5 \mathrm{~d}$ & $10 \mathrm{~d}$ & $15 \mathrm{~d}$ & \\
\hline \multirow[t]{5}{*}{ Lactic acid bacteria } & $\mathrm{C}$ & $6.18^{\mathrm{a}}$ & $5.29^{\mathrm{ab}}$ & $4.45^{\mathrm{bc}}$ & $4.10^{\mathrm{cd}}$ & $4.09^{\mathrm{cd}}$ \\
\hline & $\mathrm{SN}$ & $6.07^{\mathrm{a}}$ & $4.28^{\mathrm{bcd}}$ & $3.28^{\mathrm{d}}$ & $3.89^{\mathrm{cd}}$ & $3.98^{\mathrm{cd}}$ \\
\hline & $\mathrm{AV}$ & $5.85^{\mathrm{a}}$ & $4.63^{\mathrm{bc}}$ & $4.16^{\mathrm{cd}}$ & $3.69^{\mathrm{cd}}$ & $4.37^{\mathrm{bc}}$ \\
\hline & SNAV & $5.89^{\mathrm{a}}$ & $4.71^{\mathrm{bc}}$ & $4.52^{\mathrm{bc}}$ & $4.53^{\mathrm{bc}}$ & $4.62^{\mathrm{bc}}$ \\
\hline & SEM & 0.37 & & & & \\
\hline \multirow[t]{5}{*}{ Total mesophilic aerob bacteria } & $\mathrm{C}$ & $6.58^{\mathrm{a}-\mathrm{d}}$ & $5.44^{\mathrm{i}-1}$ & $5.97^{\mathrm{d}-\mathrm{i}}$ & $6.48^{\mathrm{a}-\mathrm{e}}$ & $7.10^{\mathrm{a}}$ \\
\hline & SN & $6.39^{\mathrm{b}-\mathrm{f}}$ & $5.05^{\mathrm{jkl}}$ & $5.81^{\mathrm{f}-\mathrm{i}}$ & $6.16^{\mathrm{c}-\mathrm{h}}$ & $6.75^{\mathrm{abc}}$ \\
\hline & AV & $6.27^{\mathrm{b}-\mathrm{h}}$ & $5.00^{\mathrm{kl}}$ & $5.63^{\mathrm{h}-\mathrm{k}}$ & $5.87^{\mathrm{e}-\mathrm{i}}$ & $6.41^{\mathrm{b}-\mathrm{f}}$ \\
\hline & SNAV & $6.33^{\mathrm{b}-\mathrm{g}}$ & $4.80^{1}$ & $5.68^{\mathrm{g}-\mathrm{j}}$ & $6.09^{c-i}$ & $6.91^{\mathrm{ab}}$ \\
\hline & SEM & 0.22 & & & & \\
\hline \multirow[t]{5}{*}{ Mold and yeast } & $\mathrm{C}$ & $5.32^{\mathrm{ab}}$ & $5.46^{\mathrm{a}}$ & $4.91^{\mathrm{abc}}$ & $4.98^{\mathrm{abc}}$ & $4.99^{\mathrm{abc}}$ \\
\hline & $\mathrm{SN}$ & $5.31^{\mathrm{ab}}$ & $4.63^{\mathrm{abc}}$ & $4.69^{\mathrm{abc}}$ & $5.15^{\mathrm{abc}}$ & $5.08^{\mathrm{abc}}$ \\
\hline & AV & $5.29^{\mathrm{ab}}$ & $5.14^{\mathrm{abc}}$ & $4.45^{\mathrm{bc}}$ & $4.33^{\mathrm{c}}$ & $4.79^{\mathrm{abc}}$ \\
\hline & SNAV & $5.19^{\mathrm{abc}}$ & $4.80^{\mathrm{abc}}$ & $4.86^{\mathrm{abc}}$ & $5.14^{\mathrm{abc}}$ & $4.65^{\mathrm{abc}}$ \\
\hline & SEM & 0.42 & & & & \\
\hline \multirow[t]{5}{*}{ Coliforms } & $\mathrm{C}$ & $5.16^{\mathrm{a}-\mathrm{d}}$ & $4.99^{\mathrm{a}-\mathrm{e}}$ & $5.80^{\mathrm{a}}$ & $5.86^{\mathrm{a}}$ & $5.55^{\mathrm{ab}}$ \\
\hline & SN & $5.18^{\mathrm{a}-\mathrm{d}}$ & $3.95^{\mathrm{e}}$ & $5.13^{\mathrm{a}-\mathrm{e}}$ & $4.88^{\mathrm{a}-\mathrm{e}}$ & $4.58^{\mathrm{b}-\mathrm{e}}$ \\
\hline & $\mathrm{AV}$ & $4.72^{\mathrm{a}-\mathrm{e}}$ & $4.03^{\mathrm{de}}$ & $5.35^{\mathrm{abc}}$ & $4.86^{\mathrm{a}-\mathrm{e}}$ & $4.76^{\mathrm{a}-\mathrm{e}}$ \\
\hline & SNAV & $5.22^{\mathrm{a}-\mathrm{d}}$ & $4.56^{\mathrm{b}-\mathrm{e}}$ & $4.70^{\mathrm{a}-\mathrm{e}}$ & $5.04^{\mathrm{a}-\mathrm{e}}$ & $4.18^{\text {cde }}$ \\
\hline & SEM & 0.42 & & & & \\
\hline
\end{tabular}

SEM standard error of the mean. All values are the mean of three replicates $(\mathrm{n}=9)$. Treatment abbreviations; $C$ no Aloe vera and sodium nitrite, SN 156 ppm sodium nitrite, AV $1 \%$ Aloe vera, SNAV $1 \%$ Aloe vera +156 ppm sodium nitrite. ${ }^{\mathrm{a}-\mathrm{k}}$ Different letters within both a column and line in each parameter are significantly different $(P<0.05)$

respectively, compared to control. Research results showed that the use of the combination of Aloe vera extract and sodium nitrite in the sausage processing is a beneficial approach for inhibiting lipid oxidation in the product.

Acknowledgements The authors would like to thank to Burdur Mehmet Akif Ersoy Universty, Scientific Research Projects Coordinatorship (Project No: 0463-YL-17) for the financial support of this project.

Author contribution EU, GBK and BK contributed to the design of the study and performed the experiments. GBK and BK contributed to the writing of the manuscript.

Data availability All data generated or analysed during this study are included in this published article.

\section{Declarations}

Conflict of interest Authors do not have any conflict of interests to disclose nor do they endorse the use of any product/technology/service over the other.

\section{References}

AOAC (2012) Official methods of analysis. In: Latimer GW (ed), 19 th edn. Association of official analytical chemists, Gaithersburg, MD

Bondi M, Lauková A, de Niederhausern S, Messi P, Papadopoulou C (2017) Natural preservatives to improve food quality and safety. J Food Qual 2017:1090932. https://doi.org/10.1155/2017/ 1090932

Bozkurt H, Bayram M (2006) Colour and textural attributes of sucuk during ripening. Meat Sci 73(2):344-350

Chatterjee R, Singh D, Dimri AG, Pandita A, Chaudhary S, Aggarwal ML (2015) Comparative study of antimicrobial activity of Aloe vera gel and antibiotics against isolates from fast food. J Pharm Pharm Sci 4(4):1058-1073

Colak H, Hampikyan H, Ulusoy B, Bingol EB (2007) Presence of Listeria monocytogenes in Turkish style fermented sausage (Sucuk). Food Control 18:30-32

Degirmencioglu MA, Gokgozoglu İ, Tavsanlı H (2006) A research on determination of changes in properties of sausages ripened by classical type and heat treatment. Turkey 9th Food Congress. Balikesir Univ Susurluk Vocational High School, Susurluk, Balikesir, pp 24-26

Flores M, Olivares A (2014) Flavor. In handbook of fermented meat and poultry. Wiley, New York, pp 217-225 
Galanakis CM (2015) Separation of functional macromolecules and micromolecules: from ultrafiltration to the border of nanofiltration. Trends Food Sci Technol 42(1):44-63

Galanakis CM (2020) The food systems in the era of the coronavirus (COVID-19) pandemic crisis. Foods 9(4):523

Galanakis CM (2021) Functionality of food components and emerging technologies. Foods 10(1):128

Galanakis CM, Aldawoud T, Rizou M, Rowan NJ, Ibrahim SA (2020) Food ingredients and active compounds against the Coronavirus disease (COVID-19) pandemic: a comprehensive review. Foods 9(11): 1701

Galanakis CM, Rizou M, Aldawoud TMS, Ucak I, Rowan NJ (2021) Innovations and technology disruptions in the food sector within the COVID-19 pandemic and post-lockdown era. Trends Food Sci Technol 110:193-200

Gharibi D, Khosravi M, Hosseini Z (2015) Antibacterial effects of Aloe vera extracts on some human and animal bacterial pathogens. J Med Microbiol Infect Dis 3(1-2):6-10

Goudarzi M, Fazeli M, Azad M, Seyedjavadi SS, Mousavi R (2015) Aloe vera gel: Effective therapeutic agent against multidrugresistant Pseudomonas aeruginosa isolates recovered from burn wound infections. Chemother Res Pract 2015:1-5

Hammes W, Haller D, Gänzle M (2008) In: Farnworth E (ed) Handbook of fermented functional foods. Fermented Meat. CRC Press, pp 291-321

Hansen TB, Nilsen NL, Christensen BB, Aabo S (2016) Enterococci as indicator of potential growth of Salmonella in fresh minced meat at retail. Food Microbiol 59:92-96

Hayat MK, Kumar T, Ahmad N, Ahmad JS, Sajjad W, Faisal S, Gao B, Khan K, Rahman Z, Abbasi B (2016) In vitro antimicrobial activity of Aloe vera $\mathrm{L}$. extracts against pathogenic bacteria and fungi. Mycopath 14(1):21-27

Holck A, Axelsson L, McLeod A, Rode TM, Heir E (2017) Health and safety considerations of fermented sausages. J Food Qual 2017:1-25

Hu Y, Xu J, Hu Q (2003) Evaluation of antioxidant potential of aloe vera (Aloe barbadensis Miller) extracts. J Agric Food Chem 51(26):7788-7791

Hullberg A, Lundström K (2004) The effects of RN genotype and tumbling on processing yield in cured-smoked pork loins. Meat Sci 67:409-419

Ju MG, Kim JH, Jang HJ, Yeon SJ, Hong GE, Park W, Seo HG, Lee $\mathrm{CH}$ (2016) Changes of physicochemical and sensory properties of fermented sausage from Sulfur-fed Pork. Korean J Food Sci Anim Resour 36(6):729-736

Jung JH, Shim KS, Shin D (2015) Effects of ripening duration and rosemary powder addition on salchichon modified sausage quality. Asian Australas J Anim Sci 28(5):671-676

Kameník J, Saláková A, Bořilová G, Pavlík Z (2012) Effect of storage temperature on the quality of dry fermented sausage poličan. Eva Standarová and Ladislav Steinhauser. Czech J Food Sci 30(4):293-301

Kang DH, Fung DYC (2000) Stimulation of starter culture for further reduction of foodborne pathogens during salami fermentation. J Food Prot 63:1492-1495

Karpagam T, Devaraj RA (2011) Studies on the efficacy of Aloe vera on antimicrobial activity. Int $\mathrm{J}$ Res Ayurveda Pharm 2(4):1286-1289

Kılıç B, Şimşek A, Claus JR, Karaca E, Bilecen D (2018) Improving lipid oxidation inhibition in cooked beef hamburger patties during refrigerated storage with encapsulated polyphosphate incorporation. LWT-Food Sci Technol 92:290-296

Kilic B (2009) Current trends in traditional Turkish meat products and cuisine. LWT-Food Sci Technol 42(10):1581-1589

Kianiani S, Varidi MJ, Varidi M (2019) The effect of fat replacement by aloe vera gel on physicochemical, technological and sensory properties of sausage containing $40 \%$ red meat. Iranian Food Sci Technol Res J 15(1):1-11

Kim DH, Shin DM, Seo HG, Han SG (2019) Effects of konjac gel with vegetable powders as fat replacers in frankfurter-type sausage. Asian-Australas J Anim Sci 32(8):1195

Kumar S, Yadav M, Yadav A, Yadav PJP (2015) Comparative analysis of antimicrobial activity of methanolic extracts of Aloe vera and quantification of Aloe- emodin collected from different climatic zones of India. Arch Clin Microbiol 6(2):1

Kumar Y, Tyagi SK, Vishwakarma RK, Kalia A (2017) Textural, microstructural, and dynamic rheological properties of low-fat meat emulsion containing aloe gel as potential fat replacer. Int $\mathbf{J}$ Food Prop 20(sup1):S1132-S1144

Lucini L, Pellizzoni M, Molinari GP, Franchi F (2012) Aloe anthraquinones against cancer. Med Aromat Plant Sci Biotechnol 5:20-24

Meena D, Suradkar US, Chavhan DM, Singh H, Yadav S (2019) Effect of different level Aloe vera gel and mint extract incorporation in the development of chicken meat cutlets. Int $\mathrm{J}$ Chem Stud 7(1):964-967

Mhalla D, Bouaziz A, Ennouri K, Chawech R, Smaoui S, Jarraya R, Tounsi S, Trigui M (2017) Antimicrobial activity and bioguided fractionation of Rumex tingitanus extracts for meat preservation. Meat Sci 125:22-29

Nejatzadeh-Barandozi F (2013) Antibacterial activities and antioxidant capacity of Aloe vera. Org Med Chem Lett 3:5

Noor S, Bhat ZF, Kumar S, Mudiyanselage RJ (2018) Preservative effect of Asparagus racemosus: a novel additive for bioactive edible films for improved lipid oxidative stability and storage quality of meat products. Meat Sci 139:207-212

Öksüztepe G, Güran HŞ, İncili GK, Gül SB (2011) Microbiological and chemical quality of sausages marketed in Elazı $\breve{g}$. FU Sağ Bil Vet Derg 25(3):107-114

Özer CO, Kılıç B, Kılıç GB (2016) In-vitro microbial production of conjugated linoleic acid by probiotic L. plantarum strains: utilization as a functional starter culture in sucuk fermentation. Meat Sci 114:24-31

Rajkumar V, Verma AK, Patra G, Pradhan S, Biswas S, Chauhan P, Das K (2016) Quality and acceptability of meat nuggets with fresh Aloe vera gel. Asian-Australas J Anim Sci 29(5):702-708

Rizou M, Galanakis IM, Aldawoud TM, Galanakis CM (2020) Safety of foods, food supply chain and environment within the COVID19 pandemic. Trends Food Sci Technol 102:293-299

Sari A, Mirmoeini S, Daraei GA (2017) Effect of Aloe vera gel on oil absorption and organoleptical properties of fried chicken meat. Iranian J Nutr Sci Food Technol 12(3):55-64

Seong AY, Seong EP, Seong HS, Hong SS (2016) Quality characteristics of fermented sausage prepared with soy sauce. Food Sci Biotechnol 25(2):533-539

Soltanizadeh N, Ghiasi-Esfahani H (2015) Qualitative improvement of low meat beef burger using Aloe vera. Meat Sci 99:75-80

Surjushe A, Vasani R, Saple DG (2008) Aloe vera: a short review. Indian J Dermatol 53:163-166

Toldrá F, Hui YH, Astiasaran I, Sebranek J, Talon R (2014) Handbook of fermented meat and poultry. John Wiley \& Sons, Hoboken

TSE (2012) Turkish Sausage TS1070. Turkish Standards Institute, Ministries, Ankara

\section{Publisher's Note}

Springer Nature remains neutral with regard to jurisdictional claims in published maps and institutional affiliations. 